\title{
An effective correlation in predicting the viscosity of biodiesel mixture over wide temperature and volume fraction ranges
}

\author{
Ali Akbar Amooey Amooey ${ }^{1}$ and abbasali alijamaati ${ }^{1}$ \\ ${ }^{1}$ Affiliation not available
}

July 6, 2020

\begin{abstract}
Biodiesel viscosity is one of the most important parameters in terms of impact on motor performance. In this study, an effective equation introduces for the kinematic viscosity of the biodiesel mixture which can be used for a wide range of temperatures and for different volume fraction systems for biodiesel mixtures. This equation is based on 1215 data from the literature. And the ability of this equation was compared with the other equations such as Arrhenius, Kendall \& Monroe and Bingham. The results show that the new equation has better performance (lower AARE\%)than the mentioned equations, and the mean error of this equation is $3.309 \%$.
\end{abstract}

\section{Hosted file}

manuscript.docx available at https://authorea.com/users/340254/articles/467348-an-effectivecorrelation-in-predicting-the-viscosity-of-biodiesel-mixture-over-wide-temperature-andvolume-fraction-ranges 